NOTE

\title{
Ovacystis-like condition in the eastern oyster Crassostrea virginica from the northeastern Gulf of Mexico
}

\author{
James T. Winstead*, Lee A. Courtney \\ US Environmental Protection Agency, National Health and Environmental Effects Research Laboratory, Gulf Ecology Division, \\ 1 Sabine Island Drive, Gulf Breeze, Florida 32561, USA
}

\begin{abstract}
Histological examination of the eastern oyster Crassostrea virginica from a study in Pensacola Bay, Florida, revealed 2 cases of abnormally large, basophilic ova that resembled cells characteristic of ovacystis disease previously reported in oysters from Maine and Long Island. The hypertrophied gametes measured up to $250 \mu \mathrm{m}$ in diameter, had scant cytoplasm and contained granular nuclear-masses of Feulgen-positive material. Electron microscopy of reclaimed tissue revealed these masses to consist of virus-like particles (average $46 \mathrm{~nm}$ ) similar to those reported in cases of ovacystis.
\end{abstract}

KEY WORDS: Crassostrea virginica - Ovacystis · Ova · Virus-like

Resale or republication not permitted without written consent of the publisher

Ovacystis is a germinal papilloma virus-like disease reported in the eastern oyster, Crassostrea virginica, from the Piscataqua River, Maine (Farley 1976, 1978), and from Long Island, New York (Meyers 1981). The disease is characterized by extensive hypertrophy of ova in which are found dense masses of basophilic, Feulgen-positive material in the nuclei of the infected cells. Transmission electron microscopy (TEM) of this material reveals non-enveloped, 5- and 6-sided (in section) viral particles averaging $53 \mathrm{~nm}$ in diameter (Sparks 1985). The condition appears to have little pathologic significance in the affected individuals (Meyers 1981). Farley (pers. comm.) has observed similar large basophilic cells in gonadal tissue of C. virginica from Mobile Bay, Alabama; however, no TEM was performed to confirm viral bodies in these cases.

Gametogenic lesions similar to those described in Crassostrea virginica have been observed in other oyster species including C. gigas, Saccostrea glomerata (formerly S. commercialis), Ostrea lurida and O. edulis (Farley 1978). Furthermore, Feulgen-positive, intranuclear inclusions have been reported in connective tissues, hemocytes and gill epithelium of Mya arenaria. These inclusions were associated with non-enveloped, icosahedral virions (40 to $45 \mathrm{~nm}$ ), resembling Polyomavirus (Farley 1978, Harshbarger et al. 1979). In this note, we report the occurrence of a ovacystis-like condition in $C$. virginica from the northeastern Gulf of Mexico.

Materials and methods. In 1996 and 1997, oysters obtained from Apalachicola Bay, Florida, were used for a caged-oyster study in Pensacola Bay, Florida. Over a 5 mo period, 160 animals were sampled for routine histological evaluation to assess potential biomarkers of stress induced by pollution. These examinations revealed 2 cases $(1.3 \%)$ of oysters with abnormally large, basophilic ova reaching up to $250 \mu \mathrm{m}$ in diameter (Fig. 1). In contrast, normal ova attain a maximum size of approximately $75 \mu \mathrm{m}$ (Galtsoff 1964). The hypertrophied ova had scant cytoplasm, and their

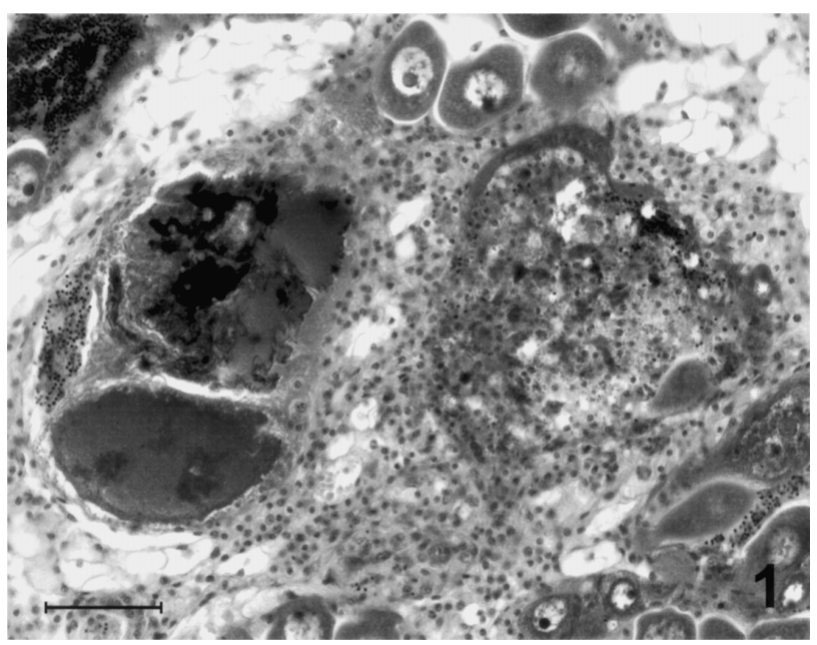

Fig. 1. Crassostrea virginica. Light micrograph showing normal and virus-infected hypertrophied ova from the gonad. Note extensive hemocytic infiltration responding to lysed ova. Scale bar $=50 \mu \mathrm{m}$ 


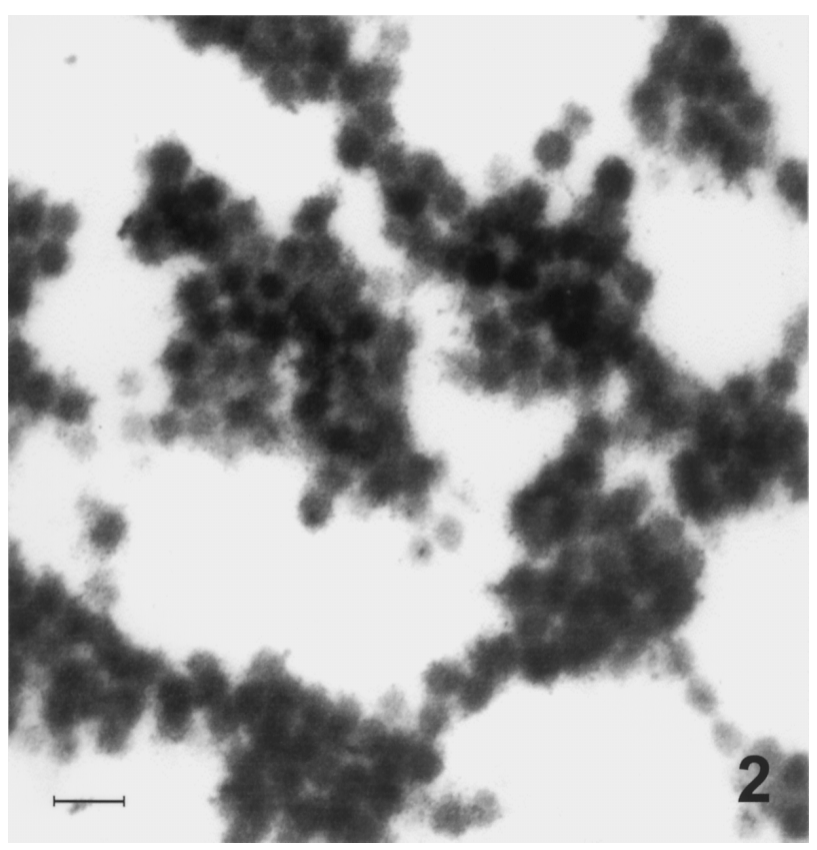

Fig. 2. Crassostrea virginica. Transmission electron microscopy (TEM) of reclaimed, paraffin-embedded tissue showing nonenveloped, 6-sided viral-like particles within the granular nuclear inclusion in hypertrophied ova. Scale bar $=100 \mathrm{~nm}$

nuclei contained large granular masses, which stained Feulgen-positive, thereby indicating high concentrations of DNA. Electron microscopy of reclaimed paraffin-embedded tissue from these lesions showed the granular masses to consist of a homogeneous amalgamation of 6-sided (in section), virus-like particles (Fig. 2) ranging in size from 43 to $52 \mathrm{~nm}$ (average $46 \mathrm{~nm}$ ). Based on the quality of the reclaimed TEM material, these particles appeared similar to the nonenveloped particles reported by Sparks (1985). Pathologic response to the condition was limited to a light to moderate hemocytic infiltration (Fig. 1) that could be in response to lysis of affected ova.

Discussion. Whether the oysters were infected in Apalachicola Bay or became infected after introduction into the Pensacola sites some $220 \mathrm{~km}$ west of

Editorial responsibility: Albert Sparks,

Seattle, Washington, USA
Apalachicola is not known. However, histological examination of 130 oysters by Fisher et al. (1996) from the same sampling sites in Apalachicola Bay a year prior to this report detected no such hypertrophied cells.

The consistencies observed in the lesions described here, compared with those reported from Crassostrea virginica from the northeastern United States, strongly suggest these cases to be ovacystis. If ovacystis, the infections in the Gulf of Mexico would represent a significant extension of the range of the disease. Although higher quality TEM should aid in this determination, obtaining good TEM results is difficult because of the low prevalence of the condition and inability for one to identify its presence and location within the host without histological examination. Nevertheless, the reclaimed material provided reasonable evidence of an agent identical to that previously reported by Farley (1976).

Acknowledgements. The authors would like to thank Dr. Robin Overstreet for his critical review of the manuscript. This is GED Contribution No. 1167.

\section{LITERATURE CITED}

Farley CA (1976) Ultrastructural observations on epizootic neoplasia and lytic virus infection in bivalve mollusks. Prog Exp Tumor Res 20:283-294

Farley CA (1978) Viruses and virus-like lesions in marine molluscs. Mar Fish Rev 40:18-20

Fisher WS, Winstead JT, Oliver LM, Edmiston HL, Bailey GO (1996) Physiologic variability of eastern oysters from Apalachicola Bay, Florida. J Shellfish Res 15:543-553

Galtsolff PS (1964) The American oyster Crassostrea virginica Gmelin. Fish Bull Fish Wildl Serv 64:1-480

Harshbarger JC, Otto SV, Chang SC (1979) Proliferative disorders in Crassostrea virginica and Mya arenaria from the Chesapeake Bay and intranuclear virus-like inclusions in Mya arenaria with germinomas from a Maine oil spill site. Haliotis 8:243-248

Meyers TR (1981) Endemic diseases of cultured shellfish of Long Island, New York: adult and juvenile American oysters (Crassostrea virginica) and hard clams (Mercenaria mercenaria). Aquaculture 22:305-330

Sparks AK (1985) Synopsis of invertebrate pathology exclusive of insects. Elsevier Science Publishers, Amsterdam

Submitted: June 24, 2002; Accepted: September 23, 2002 Proofs received from author(s): January 6, 2003 